\title{
Inhibition of ovulation, steroidogenesis and collagenolytic activity in rabbits by sulpiride-induced hyperprolactinaemia*
}

\author{
K. C. Lin, N. Kawamura, H. Okamura† and T. Mori
}

Department of Gynaecology and Obstetrics, Kyoto University Faculty of Medicine, Sakyo-ku, Kyoto 606, Japan, and † Department of Obstetrics and Gynaecology, Kumamoto University Medical School, Kumamoto 860, Japan

\begin{abstract}
Summary. Ovulation induced by hCG in rabbits was reduced significantly $(P<0.005)$ by sulpiride-induced hyperprolactinaemia. The pre- and post-ovulatory increases in peripheral and ovarian venous progesterone (but not oestradiol or testosterone) were suppressed in the treated animals. The condition of hyperprolactinaemia also prevented the usual changes in 2,4-dinitrophenyl-Pro-Gln-Gly-Ile-Ala-Gly-Gln-D-ArgOH peptidase (DNP-peptidase) and $\alpha$ - $N$-benzoyl-DL-Arg- $\beta$-naphthylamide hydrolase (BANA-hydrolase) activities in follicular tissue that had been stimulated by an ovulatory dose of hCG. These results suggest that inhibition of progesterone production and collagenolytic enzyme activity by sulpiride-induced hyperprolactinaemia may be responsible for the ovulatory dysfunction that occurs when a mammal has a high level of circulating prolactin.
\end{abstract}

Keywords: ovulation; steroidogenesis; proteolytic enzyme; hyperprolactinaemia; rabbit

\section{Introduction}

Sulpiride has been used extensively to induce hyperprolactinaemia and to study how this condition affects the menstrual cycle (L'Hermite et al., 1978a; Aso et al., 1982). However, it is not yet clear whether the abnormal elevation in circulating prolactin has a direct effect on ovulation, the principal event of the menstrual cycle which occurs as a consequence of a number of complex biochemical events in the ovary (Espey, 1980). Ovarian steroidogenesis has been demonstrated to be one of the important events leading to ovulation by the observation that the administration of inhibitors of steroidogenesis could block ovulation in rats (Lipner \& Greep, 1971). The connective tissue of the ovarian follicle undergoes deterioration and this change is associated with dissociation of the follicular collagen before ovulation (Espey, 1967; Okamura et al., 1980). Collagenolytic enzyme activity in the ovary is observed with $\alpha-N$-benzoyl-DL-Arg- $\beta$-naphthylamide (BANA) as the substrate, and this activity changes in relation to ovulation (Fukumoto et al., 1981; Kawamura et al., 1984). Moreover, collagen-analogous synthetic substrate, 2,4-dinitrophenyl(DNP)-Pro-Leu-GlyIle-Ala-Gln-D-Arg peptide, digestible activity is observed in the Graafian follicle (Morales et al., 1978; Okamura et al., 1985). In an effort to clarify the mechanism by which prolactin interferes with these chemical events of ovulation, we have injected sulpiride-treated hyperprolactinaemic rabbits with an ovulatory dose of hCG and then measured (a) peripheral and ovarian venous concentrations of oestradiol, progesterone and testosterone, and (b) the ovarian tissue levels of DNP-Pro-Gln-Gly-Ile-Ala-Gly-Gln-D-Arg-OH peptidase (DNP-peptidase) and BANA-hydrolase.

\footnotetext{
*Reprint requests to Dr H. Okamura.
} 


\section{Materials and Methods}

Animals. Virgin Japanese White rabbits were used. These 48 sexually mature animals weighed $2 \cdot 8-3 \cdot 5 \mathrm{~kg}$. They were housed in air-conditioned quarters with a daily light cycle of $14 \mathrm{~h}$ and fed pressed food and water ad libitum for a minimum of 3 weeks before use.

Induction of hyperprolactinaemia. Hyperprolactinaemia was induced by injecting sulpiride (Fujisawa Pharmaceutical Co. Ltd, Tokyo, Japan) into the subcutaneous tissue of the neck at a dose of $8 \mathrm{mg} / \mathrm{kg} 3$ times daily (at 09:00, 14:00 and $19: 00 \mathrm{~h})$ for 4 days. Control animals were injected with saline $(0.9 \% \mathrm{w} / \mathrm{v})$ only.

Blood sample collection. Peripheral blood samples were taken with the heparinized syringe from the marginal ear vein. Ovarian venous blood was withdrawn through a 25 -gauge hypodermic needle after the rabbits were anaesthetized with pentobarbitone sodium and a laparotomy was performed. All samples were stored at $-20^{\circ} \mathrm{C}$ until assayed for the specified hormones.

Ovulation induction and confirmation. At $20: 00 \mathrm{~h}$ on the 4th day of sulpiride treatment, the experimental animals were injected in the marginal ear vein with 100 i.u. hCG (Mochida Pharmaceutical Co. Ltd, Tokyo, Japan). Ovulation was confirmed $14 \mathrm{~h}$ later by observing the number of ruptured follicles or fresh corpora lutea on each ovary under a dissecting microscope.

Follicle collection and extraction. Whole ovaries were placed on a chilled plate under a dissecting microscope. The mature follicles ( $>1 \mathrm{~mm}$ in diameter) were cut free of the stromal connective tissue and proportionally distributed into two groups for the assay of DNP-peptidase and BANA-hydrolase activity, respectively. They were frozen at $-70^{\circ} \mathrm{C}$ until assays were performed.

Prolactin assay. Plasma prolactin concentrations were determined by a specific homologous double-antibody radioimmunoassay kit (National Hormone and Pituitary Program, Baltimore, MD, U.S.A.). Highly purified rabbit prolactin (NIADDK-AFP-1974-C) was used for the standard curve and for radioiodination, which was performed by a modified lactoperoxidase procedure (Frantz \& Turkington, 1972; Harigaya et al., 1982). Initially, the assay tubes contained $100 \mu \mathrm{l}$ diluted rabbit plasma (or prolactin standard), $100 \mu \mathrm{l} 0.05 \mathrm{M}$-phosphate-buffered saline (PBS, containing $1 \%$ bovine serum albumin, and $2.7 \mathrm{~mm}$-EDTA), and $100 \mu \mathrm{l}$ of rat anti-rabbit prolactin serum (NIADDK-AFP18102677 , diluted $\times 200000$ with PBS containing $2 \%$ normal rat serum). These tubes were incubated at $4^{\circ} \mathrm{C}$ for $48 \mathrm{~h}$ and then $100 \mu \mathrm{l}^{125} \mathrm{I}$-labelled prolactin (containing 15000-20000 c.p.m.) were added to each tube and they were incubated for another $24 \mathrm{~h}$. Finally, $200 \mu \mathrm{l}$ of a 1:20 dilution of goat anti-rat gamma globulin (Cappel Laboratories, Cochranville, PA, U.S.A.) were added to the assay tubes and they were incubated for another $48 \mathrm{~h}$. At the end of this incubation, the tubes were centrifuged at $2000 \mathrm{~g}$ for $30 \mathrm{~min}$ to separate the bound and free ${ }^{125} \mathrm{I}$-labelled prolactin. The radioactivity in the pellet was counted after aspirating the supernatant. The assay sensitivity was $0.39 \mathrm{ng} / \mathrm{ml}$. The intra- and interassay coefficients of variation were $8.9 \%$ and $13.5 \%$, respectively, for the duplicate samples.

Gonadotrophin assays. Plasma LH and FSH concentrations were measured by specific double-antibody radioimmunoassay kits (National Hormone and Pituitary Program). Highly purified rabbit LH (NIADDK-AFP-559-3) and FSH (NIADDK-AFP-538-C) were used for the standard curves and for radioiodination, which was performed by a lactoperoxidase method (Miyachi $e t$ al., 1972). Guinea-pig antisera against rabbit LH (NIADDK-AFP-81-28) and FSH (NIADDK-AFP-4-7-21-76) were supplied with the kits. Initially, the assay tubes contained $100 \mu 1$ rabbit plasma (or $100 \mu \mathrm{l} \mathrm{LH}$ or FSH standard), $100 \mu \mathrm{l} 0.05 \mathrm{M}$-PBS and $100 \mu \mathrm{l}$ of the anti-rabbit LH or FSH (diluted $\times 900000$ and $\times 52000$, respectively, with PBS). These tubes were incubated at $4^{\circ} \mathrm{C}$ for $24 \mathrm{~h}$ and then $100 \mu l^{125} \mathrm{I}-$ labelled LH or FSH (containing 15000-20000 c.p.m.) was added and the tubes were incubated for another $24 \mathrm{~h}$. Subsequently, $200 \mu \mathrm{l}$ of a 1:20 dilution of goat anti-guinea-pig gamma globulin (Cappel Laboratories) were added to the assay tubes and they were incubated for an additional 84-96 h. At the end of this incubation, the tubes were centrifuged at $2000 \mathrm{~g}$ for $30 \mathrm{~min}$ to separate the bound and free ${ }^{125}$ I-labelled LH or FSH. The radioactivity in the pellet was counted after aspirating the supernatant. The sensitivity of the LH assay was $0.63 \mathrm{ng} / \mathrm{ml}$ and that of the FSH assay was $0.78 \mathrm{ng} / \mathrm{ml}$.

Steroid assays. Plasma steroids were determined by radioimmunoassay as described previously (Mori et al., 1980). Antisera against oestradiol, progesterone and testosterone were purchased from Teikoku Hormone $\mathrm{Mfg}$. Co. Ltd, Tokyo, Japan. The assay sensitivities were $10 \mathrm{pg}$ oestradiol $/ \mathrm{ml}, 25 \mathrm{pg}$ progesterone $/ \mathrm{ml}$ and $10 \mathrm{pg}$ testosterone $/ \mathrm{ml}$ plasma, respectively. The intra- and interassay coefficients of variation for all steroids were $<10 \%$ and $<15 \%$, respectively.

DNP-peptidase activity assay. The enzyme activity was assayed by the method of Morales et al. (1978) as modified by Fukumoto et al. (1981) and Kawamura et al. (1984). The follicular tissues were washed with $50 \mathrm{mM}-\mathrm{Tris}-\mathrm{HCl}$ buffer ( $\mathrm{pH} 7 \cdot 6$ ) containing $0 \cdot 15 \mathrm{M}-\mathrm{NaCl}$ and $5 \mathrm{mM}-\mathrm{CaCl}_{2}$ (assay buffer) and homogenized in the assay buffer with a glass homogenizer and a Teflon homogenizer to a concentration of $30 \mathrm{mg}$ tissue $/ \mathrm{ml}$. The homogenates were incubated at $42^{\circ} \mathrm{C}$ for $30 \mathrm{~min}$ for heat shock and cooled, then centrifuged at $20000 \mathrm{~g}$ for $10 \mathrm{~min}$. The supernatants were passed through the $45 \mu \mathrm{m}$ Millipore filter (Millipore Corp., Bedford, MA, U.S.A.) and the filtrates were used as the enzyme solution. The synthetic DNP-peptide (Peptide Institute, Protein Research Foundation, Osaka, Japan) was dissolved in assay buffer and centrifuged at $10000 \mathrm{~g}$ for $10 \mathrm{~min}$ and the supernatant was used as the substrate solution. The 
reaction mixture, which consisted of $150 \mu$ l substrate, $50 \mu$ enzyme solution and $100 \mu l$ assay buffer, was incubated at $37^{\circ} \mathrm{C}$ for $3 \mathrm{~h}$. The reaction was terminated with $300 \mu \mathrm{l} 1.0 \mathrm{~N}-\mathrm{HCl}$ and the cleaved peptide was extracted with $1.5 \mathrm{ml}$ ethyl acetate and quantitated by absorbance $(A)$ at $365 \mathrm{~nm}$. The activity was expressed as $\Delta$ optical density (OD) after the absorbance value of a 0 time incubation blank was subtracted from those of an equivalent tube that had been incubated for $3 \mathrm{~h}$.

BANA-hydrolase activity assay. The method of Barrett (1972), as confirmed by Fukumoto et al. (1981) and Kawamura et al. (1984) was used. The follicular tissues were washed with saline $(0.9 \%(\mathrm{w} / \mathrm{v}) \mathrm{NaCl})$ and homogenized in $0.25 \mathrm{M}$-sucrose containing $0.1 \%$ Triton-X 100 to a concentration of $30 \mathrm{mg}$ tissue/ml. The homogenates were centrifuged at $20000 \mathrm{~g}$ for $10 \mathrm{~min}$ and the supernatants were used as the enzyme solution. The reaction mixture, which consisted of $50 \mu \mathrm{l}$ enzyme solution, $15 \mu \mathrm{l}$ BANA substrate (Sigma, Chemical Co., St Louis, MO, U.S.A.) and $450 \mu 1$ assay buffer (0.1 M-phosphate buffer in $1 \mathrm{mM}$-EDTA, $\mathrm{pH} 6.0)$, was incubated at $37^{\circ} \mathrm{C}$ for $10 \mathrm{~min}$. The reaction was stopped by the addition of $600 \mu \mathrm{l}$ of coupling reagent, which contained $300 \mu \mathrm{l} p$-chloromercuribenzoate (Sigma) in EDTA-PBS and $300 \mu \mathrm{l} 6 \%$ Fast Garnet GBC (Sigma) and the released $\beta$-naphthylamide was extracted with $1 \cdot 2 \mathrm{ml}$ of butanol and determined by measuring the absorbance of the organic layer at $520 \mathrm{~nm}$.

Statistical analysis. The results are expressed as means \pm s.e.m. Significant differences between the groups were determined by unpaired Student's $t$ tests, except for the values of ovulation rate which were analysed by $\chi^{2}$ tests.

\section{Results}

\section{Effects of sulpriride on plasma prolactin and ovulation}

Plasma prolactin concentration increased 11 -fold during the 4 days of sulpiride treatment (Fig. 1), and was still significantly elevated at $14 \mathrm{~h}$ after hCG administration. The ovulation rate at $14 \mathrm{~h}$ after hCG was significantly lower $(P<0.005)$ in sulpiride-treated $(61.5 \%)$ than in control rabbits $(84 \cdot 1 \%)$. (The amounts of LH and FSH in all samples were below the sensitivity levels of the respective radioimmunoassays.)

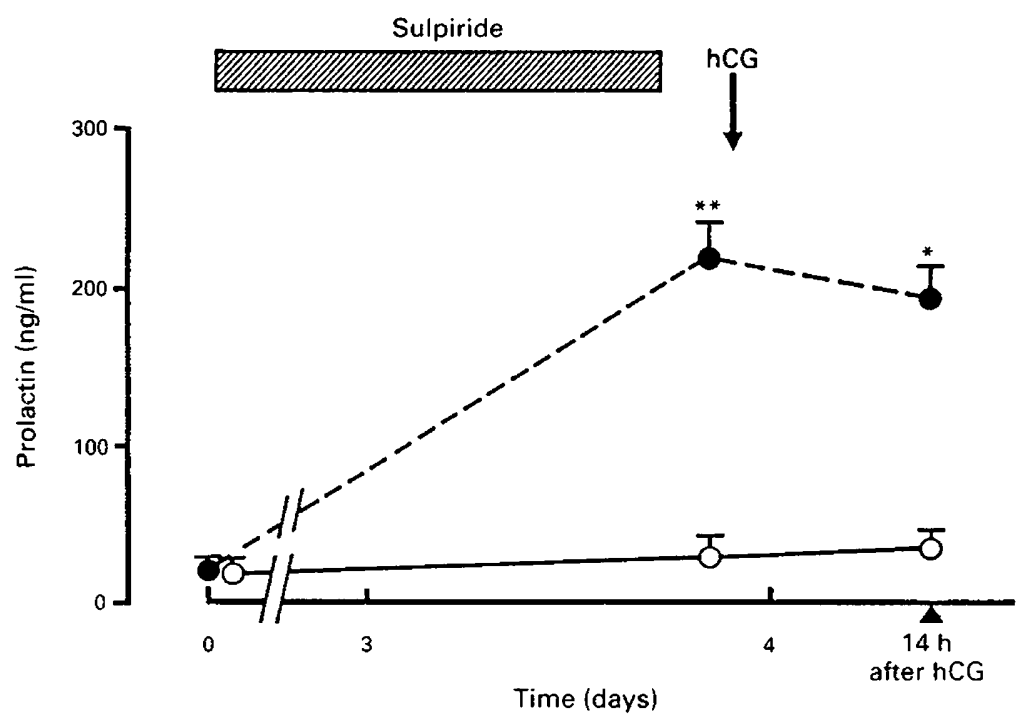

Fig. 1. Plasma prolactin concentrations in the control $(O)$ and sulpiride-treated $(O)$ animals. Transverse hatched bar indicates the period of sulpiride treatment and arrow denotes the time of hCG injection. There were 6 rabbits per group. ${ }^{*} P<0.005,{ }^{* *} P<0.001$ compared with the corresponding control values.

\section{Effect of hyperprolactinaemia on steroidogenesis}

There were no significant differences in the peripheral plasma concentrations of oestradiol, progesterone, and testosterone between the control and the sulpiride-treated rabbits during the 4 

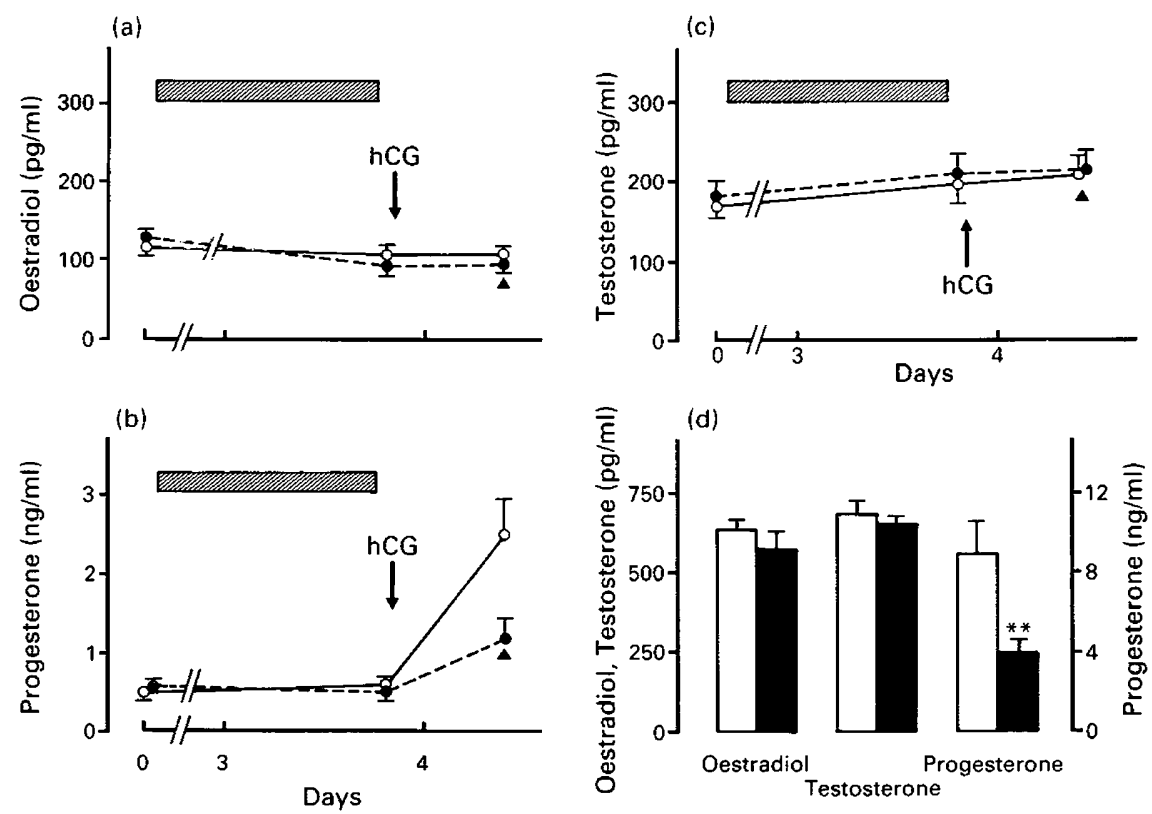

Fig. 2. Oestradiol, progesterone and testosterone concentrations in peripheral plasma (a, b, c) and ovarian (d) venous plasma of the control ( $O$ and open bars) and sulpiride-treated ( $O$ and solid bars) groups. Ovarian venous plasma was taken at $14 \mathrm{~h}$ after hCG $(\boldsymbol{\Delta})$. Transverse hatched bars indicate the period of treatment and arrows denote the time of hCG injection. There were 6 rabbits per group. ${ }^{*} P<0.05,{ }^{* *} P<0.005$ compared with the corresponding control values.

days of treatment (Fig. 2). However, at $14 \mathrm{~h}$ after hCG, peripheral progesterone (but not oestradiol or testosterone) concentrations were substantially increased, but the increase was significantly less in the sulpiride-treated animals (Fig. 2b). This difference in the progesterone values between the control and sulpiride-treated rabbit was also detected in the ovarian venous plasma at $14 \mathrm{~h}$ after hCG (Fig. 2d). The similar reduction in the peripheral progesterone concentrations in the sulpiridetreated group could be detected as early as $1-4 \mathrm{~h}$ after hCG administration (Fig. 3b), but no differences were found in the concentrations of oestradiol and testosterone (Figs 3a, c) during the same period after hCG. Also, the elevation in the ovarian venous concentration of progesterone at $4 \mathrm{~h}$ after hCG was significantly suppressed in the sulpiride-treated group as compared with the control group (Fig. 3d).

\section{Effect of hyperprolactinaemia on peptidase activities}

In the control animals, activities of DNP-peptidase and BANA-hydrolase were higher at $8 \mathrm{~h}$ after hCG than at $10 \mathrm{~h}$ after hCG when follicular rupture is more imminent (Fig. 4). In contrast, in sulpiride-treated animals, the activities of both enzymes remained elevated at $10 \mathrm{~h}$ after hCG, and were significantly higher than in the respective controls.

\section{Discussion}

This study shows that sulpiride-induced hyperprolactinaemia suppresses not only the steroidogenesis that is characteristic of ovulation, but also the usual changes in ovarian proteolytic enzymes. 

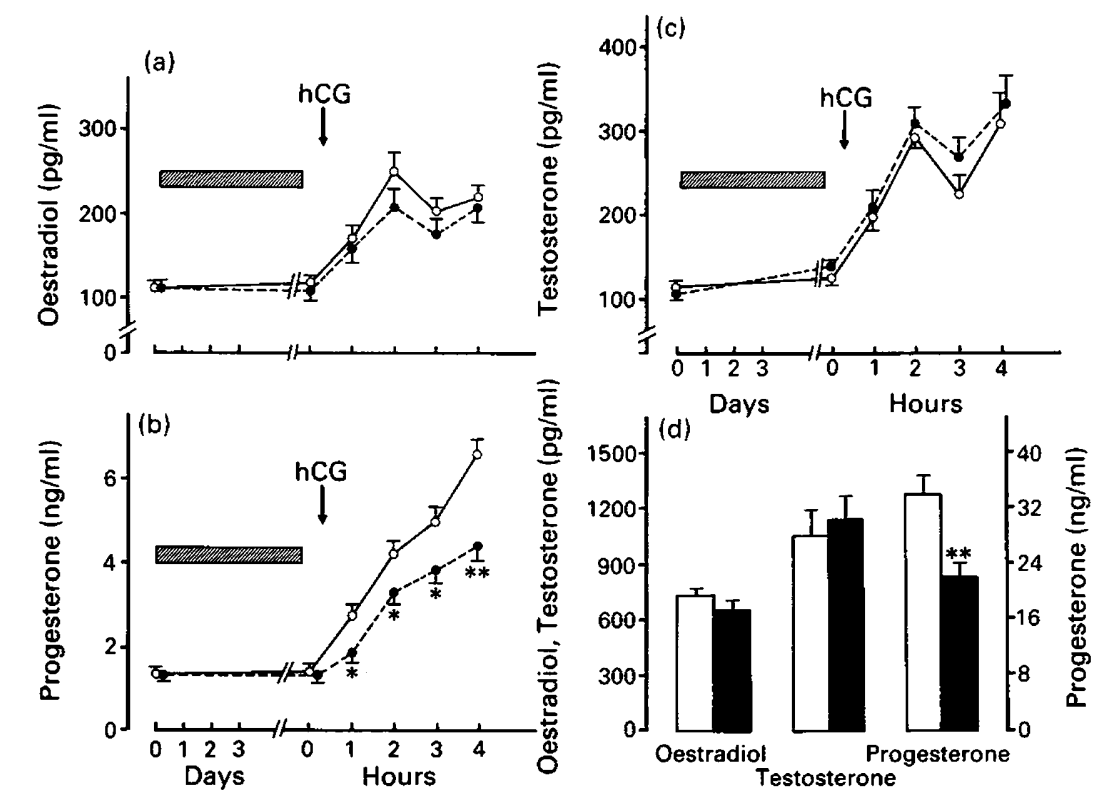

Fig. 3. Oestradiol, progesterone and testosterone in peripheral plasma (a, b, c) and ovarian (d) venous plasma of the control ( $O$ and open bars) and sulpiride-treated ( $O$ and solid bars) groups. Ovarian venous plasma was taken at $4 \mathrm{~h}$ after hCG. Transverse hatched bars indicate the period of sulpiride treatment and arrows denote the time of hCG injection. There were 6 rabbits per group. ${ }^{*} P<0.005,{ }^{* *} P<0.001$ compared with the corresponding control values.

(a) DNP-peptidase

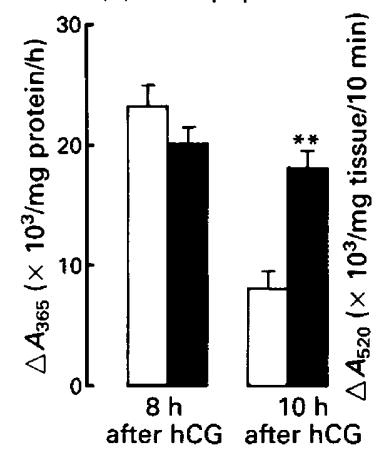

(b) BANA-hydrolase

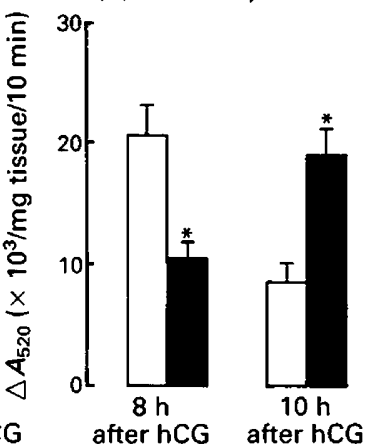

Fig. 4. DNP-peptidase (a) and BANA-hydrolase (b) enzyme activities at 8 and $10 \mathrm{~h}$ after hCG in the follicular tissues of the control (open bars) and sulpiride-treated (solid bars) rabbits. There were 3 rabbits per group per enzyme at $8 \mathrm{~h}$ and $10 \mathrm{~h}$ after hCG, respectively. ${ }^{*} P<0 \cdot 01$, ${ }^{* *} P<0.001$ compared with values of the control group.

Sulpiride is a dopamine antagonist which acts on the lactotrophes of the adenohypophysis to induce prolactin secretion (MacLeod \& Robyn, 1977), and its disruption of normal events of the menstrual cycle could be due either to some direct effect of sulpiride on endocrine mechanisms that regulate the menstrual cycle and ovulation, or to the hyperprolactinaemia that is brought about by the sulpiride treatment (L'Hermite et al., 1978b). However, the former does not seem likely since 
there are reports that this agent does not affect the tonic secretions of other pituitary hormones even if it is administered chronically throughout the follicular phase of a cycle (Robyn et al., 1977; L'Hermite et al., 1978b). Although we do not have direct evidence to confirm this report (because the LH and FSH concentrations were too low to detect), our observation that there was no significant difference in the oestradiol concentrations between the treated and untreated groups suggests that there was adequate gonadotrophin secretion for normal follicular maturation. After an ovulatory dose of hCG injection we observed a reduction in the normal pre- and postovulatory production of progesterone in the sulpiride-treated animals, demonstrating that the elevated concentration of prolactin might act directly on the granulosa cells to desensitize them to gonadotrophin stimulation. This possible direct effect at the ovarian level is supported by the results of in-vitro studies of the granulosa (McNatty et al., 1974; Demura et al., 1982). Hamada et al. (1980) also indicated that at certain high levels, prolactin, independent of hCG, interferes with follicular rupture by the observation using a preparation of the in-vitro perfused rabbit ovary.

An abrupt preovulatory rise in progesterone has been observed about $12 \mathrm{~h}$ before the midcycle LH surge in humans (Hoff et al., 1983) and within $5 \mathrm{~h}$ after mating or hCG administration in rabbits (Hilliard \& Eaton, 1971; Mills \& Savard, 1973; Wu et al., 1977). The idea that progesterone may be important in ovulation is supported by evidence that hCG-induced ovulation can be blocked by treating rats with inhibitors of $3 \beta$-hydroxysteroid dehydrogenase which interrupt the steroidogenic pathway to progesterone (Lipner \& Greep, 1971) and this blockage can be overcome by exogenous progesterone (Snyder et al., 1984). Furthermore, anti-progesterone antiserum inhibits ovulation in rats (Mori et al., 1977a), and a dose of cycloheximide that inhibits ovulation in rabbits also inhibits the normal steroidogenic activity that precedes ovulation (Espey, 1986). Collectively, these observations suggest that progesterone may be a prerequisite to ovulation. If it is true, then the inhibition of ovulation by sulpiride treatment may be a result of the decline in progesterone secretion (by granulosa cells) under the conditions of hyperprolactinaemia. However, it seems necessary to determine the concentrations of $20 \alpha$-dihydroprogesterone since it is the principal secretory product of the rabbit ovary. It may also, like progesterone, participate in the ovulatory process during this abnormal endocrine environment. Further study is in progress to clarify this point.

DNP-peptidase and BANA-hydrolase degrade native collagen at neutral and acid $\mathrm{pH}$, respectively, and there is biochemical (Morales et al., 1978; Fukumoto et al., 1981) and morphological (Espey \& Rondell, 1967; Okamura et al., 1980) evidence to suggest that such enzymes are involved in the dissociation of the collagen matrix in the follicle wall at the time of ovulation. These enzymes increase about $7 \mathrm{~h}$ after $\mathrm{hCG}$ administration and then there is a decrease in the measurable amount of activity at $1-2 \mathrm{~h}$ before follicular rupture in the rabbit (Kawamura et al., 1984; Okamura et al., 1985) and human (Fukumoto et al., 1981). The present results indicate that sulpiride-induced hyperprolactinaemia interferes with the normal preovulatory change in these collagen-degrading enzymes (e.g. production was less at $8 \mathrm{~h}$ than at $10 \mathrm{~h}$ after hCG in the follicles of the treated rabbits). Fukumoto et al. (1981) indicated that ovarian collagenolytic activity is mainly in the granulosa cells that is known to be affected by excess prolactin (McNatty et al., 1974; Robyn et al., 1977). Rondell (1974) has reported that progesterone may activate enzymes which increase the distensibility of the collagen framework of strips of sow follicles in vitro. Therefore, it is possible that prolactin exerts its antiovulatory effect by interfering with progesterone and/or collagenase metabolism in mature ovarian follicles.

Besser \& Thorner (1975) found that chronic hyperprolactinaemia reduces oestrogen synthesis and causes hypogonadism. Our failure to find any differences in the ovarian output of oestrogen between sulpiride-treated and control rabbits (Japanese White strain) may be due to the shorter duration of treatment. In any event, it is doubtful that oestrogen is important in the mechanism of ovulation because the inhibition of oestrogen synthesis does not prevent ovulation from taking place in the in-vitro perfused rat ovary (Koos et al., 1984). Likewise, it is doubtful that testosterone is a critical factor in ovulation (Mori et al., 1977b; Wu et al., 1977). 
We thank Professor L. L. Espey, Trinity University, for reading the manuscript; NIADDK and Dr A. F. Parlow for the generous supply of rabbit prolactin, LH and FSH kits; and Drs T. Harigaya and T. Okazaki for valuable advice on radioimmunoassay.

\section{References}

Aso, T., Matsuoka, M., Su, J.H., Horie, K., Taii, S., Motohashi, T. \& Nishimura, T. (1982) Influence of sulpiride-induced hyperprolactinaemia on baboon menstrual cycles: a longitudinal study. J. med. Primatol. 11, 20-34.

Barrett, A.J. (1972) A new assay for cathepsin B1 and other thiol proteinases. Analyt. Biochem. 47, 280-293.

Besser, G.M. \& Thorner, M.O. (1975) Prolactin and gonadal function. Pathol. Biol. 23, 779-782.

Demura, R., Ono, M., Demura, H., Shizume, K. \& Oouchi, H. (1982) Prolactin directly inhibits basal as well as gonadotrophin-stimulated secretion of progesterone and $17 \beta$-oestradiol in the human ovary. $J$. clin. Endocr. Metab. 54, 1246-1250.

Espey, L.L. (1967) Ultrastructure of the apex of the rabbit Graafian follicle during the ovulatory process. Endocrinology 81, 267-276.

Espey, L.L. (1980) Ovulation as an inflammatory reaction -a hypothesis. Biol. Reprod. 22, 73-106.

Espey, L.L. (1986) Cycloheximide inhibition of ovulation, prostaglandin biosynthesis, and steroidogenesis in rabbit ovarian follicles. J. Reprod. Fert. 78, 679-683.

Espey, L.L. \& Rondell, P. (1967) Collagenolytic activity in the rabbit and sow Graffian follicle during ovulation. Am. J. Physiol. 214, 326-329.

Frantz, W.L. \& Turkington, R.W. (1972) Formation of biologically active ${ }^{125} \mathrm{I}$-prolactin by enzymatic radioiodination. Endocrinology 91, 1545-1548.

Fukumoto, M., Yajima, Y., Okamura, H. \& Midorikawa, O. (1981) Collagenolytic enzyme activity in human ovary: an ovulatory enzyme system. Fert. Steril. 36, $746-750$.

Hamada, Y., Schlaff, S., Kobayashi, Y., Santulli, R., Wright, K.H. \& Wallach, E.E. (1980) Inhibitory effect of prolactin on ovulation in the in vitro perfused rabbit ovary. Nature. Lond. 285, 161-163.

Harigaya, T., Sakai, S., Kohmoto, K. \& Shoda, Y. (1982) Influence of glucocorticoids on mammary prolactin receptors in pregnant mice after ovariectomy. $J$. Endocr. 94, 149-155.

Hilliard, J. \& Eaton, L.W., Jr. (1971) Estradiol-17ß, progesterone and $20 \alpha$-hydroxypregn-4-en-3-one in rabbit ovarian venous plasma. II. From mating through implantation. Endocrinology 89, 522-527.

Hoff, J.D., Quigley, M.E. \& Yen, S.S.C. (1983) Hormonal dynamics at midcycle: a reevaluation. $J$. clin. Endocr. Metab. 57, 792-796.

Kawamura, N., Himeno, N., Okamura, H., Mori, T., Fukumoto, M. \& Midorikawa, O. (1984) Effect of indomethacin on collagenolytic enzyme activities in rabbit ovary. Acta obstet. gynecol. jap. 36, 2099-2105.

Koos, R.D., Feiertag, M.A., Brodie, A.M.H. \& LeMaire, W.J. (1984) Inhibition of oestrogen synthesis does not inhibit luteinizing hormone-induced ovulation. Am. J. Obstet. Gynecol. 148, 939-945.
L'Hermite, M., Delogne-Desnoeck, J., MichauxDuchene, A. \& Robyn, LC. (1978a) Alteration of feedback mechanism of oestrogen on gonadotrophin by sulpiride-induced hyperprolactinaemia. J. clin. Endocr. Metab. 47, 1132-1136.

L'Hermite, M., Denayer, P., Golstein, J., Virasoro, L., Vanhaelst, L., Copinschi, G. \& Robyn, C. (1978b) Acute endocrine profile of sulpiride in the human. Clin. Endocrinol. 9, 195-204.

Lipner, H. \& Greep, R.O. (1971) Inhibition of steroidogenesis at various sites in the biosynthetic pathway in relation to induced ovulation. Endocrinology $\mathbf{8 8}$, $602-607$.

MacLeod, R.M. \& Robyn, C. (1977) Mechanism of increased prolactin secretion by sulpiride. J. Endocr. 72, 273-277.

McNatty, K.P., Sawers, R.S. \& McNeilly, A.S. (1974) A possible role for prolactin in control of steroid secretion by the human Graafian follicle. Nature, Lond. 250, 653-655.

Mills, T.M. \& Savard, K. (1973) Steroidogenesis in ovarian follicles isolated from rabbits before and after mating. Endocrinology 92, 788-791.

Miyachi, Y., Vaitukaitis, J.L., Nieschlag, E. \& Lipsett, M.B. (1972) Enzymatic radioiodination of gonadotrophins. J. clin. Endocr. Metab. 34, 23-28.

Morales, T.I., Woessner, J.F., Howell, D.S., Marsh, J.M. \& LeMaire, W.J. (1978) A microassay for the direct demonstration of collagenolytic activity in Graafian follicles of the rat. Biochem. Biophys. Acta 524, 428-434.

Mori, T., Suzuki, A., Nishimura, T. \& Kambegawa, A. (1977a) Inhibition of ovulation in immature rats by anti-progesterone antiserum. J. Endocr. 73, 185-186.

Mori, T., Suzuki, A., Nishimura, T. \& Kambegawa, A. (1977b) Evidence for androgen participation in induced ovulation in immature rats. Endocrinology 101, 623-626.

Mori, T., Kohda, H., Kinoshita, Y., Ezaki, Y., Morimoto, N. \& Nishimura, T. (1980) Inhibition by indomethacin of ovulation induced by human chorionic gonadotrophin in immature rats primed with preg. nant mare serum gonadotrophin. J. Endocr. 84, 333341 .

Okamura, H., Takenaka, A., Yajima, Y. \& Nishimura, T. (1980) Ovulatory changes in the wall at the apex of the human Graafian follicle. J. Reprod. Fert. 58, $153-155$.

Okamura, H., Fukumoto, M. \& Mori, T. (1985) Prostaglandin-mediated changes of vascular and collagen degradation/synthesis in the follicle wall during ovulation. Adv. Prostagl., Thromboxane, and Leukotriene Res. 15, 597-599.

Robyn, C., Delvoye, P., Van Exter, C., Vekemans, M., Caufriez, A., de Nayer, P., Delogne-Desnceck, J. \& 
L'Hermite, M. (1977) Physiological and pharmacological factors influencing prolactin secretion and their relation to human reproduction. In Prolactin and Human Reproduction, pp. 71-96. Eds P. G. Crosignani \& C. Robyn. Academic Press, London.

Rondell, P. (1974) Role of steroid synthesis in the process of ovulation. Biol. Reprod. 10, 199-215.

Snyder, B.W., Beecham, G.D. \& Schane, H.P. (1984)

Inhibition of ovulation in rats with epostane, an inhibitor of $3 \beta$-hydroxysteroid dehydrogenase (41865). Proc. Soc. exp. Biol. Med. 176, 238-242.

Wu, C.H., Blasco, L., Flickinger, G.L. \& Mikhail, G. (1977) Ovarian function in the preovulatory rabbit. Biol. Reprod. 17, 304-308.

Received 18 September 1987 